\title{
Optimum Scheduling of Isolated Hybrid Renewable Energy System - A Case Study Using HOMER
}

\section{Ravita Saraswat ${ }^{1 *}$ and Sathans $S^{2}$}

${ }^{1}$ School of Renewable Energy and Efficiency, National Institute of Technology, Kurukshetra, Haryana, India

${ }^{2}$ Department of Electrical Engineering, National Institute of Technology, Kurukshetra, Haryana, India

\begin{abstract}
This paper compares the different scheduling scenarios of hybrid renewable energy system in terms of system configuration, economy, power production, biomass availability and pollutant emission. The hybrid renewable energy system comprises the solar, wind and biomass based power generating systems. This case study is carried out for a specific geographical location (village Ramgarh) in Ambala district of Haryana state, in India. The HOMER software tool is used to carry out simulations of three different scenarios viz. Generator is on or off depending on the availability of solar and wind power; the generator is on for all time; and the generator operation is optimized. Sensitivity analysis is also carried out for different maximum annual capacity storage in relation to change in net present cost (NPC) and levelized cost of energy (LCOE). The results of the analysis indicate that as the maximum annual capacity storage increases, the net present cost and levelized cost of energy decreases. The comparison of the results is presented in a tabular form.
\end{abstract}

Keywords: Solar energy; Wind energy; Biomass; Net present cost; Levelized cost of energy

\section{Introduction}

Electrical energy is a basic necessity of everyday life [1]. The world energy demand is increasing rapidly which we are not able to meet and even today 1.4 billion people are still lacking electricity [2]. Now it is high time to exploit the renewable energy resources instead of fossil fuels to produce electricity which will not have adverse effect on the climate behaviour [3]. The high participation of renewable energy sources is need of the hour not only for grid connected load, but also for stand-alone systems [4]. The use of hybrid renewable energy systems, which includes two or more energy sources having at least one of these resources as renewable, is being pursued [5]. However, there are challenges in the design of hybrid renewable energy systems due to the variability and availability of renewable energy sources which affect the performance of hybrid systems all through the year and hence the renewable sources can be considered in terms of average value and distributed over year [6].

Lot of studies have been reported on hybrid system in respect of their design optimization. Jose et al. [7] conducted a design study of hybrid system for minimizing costs and pollutants emissions. Lopez et al. [8] performed optimization of control strategies for stand-alone renewable energy system with hydrogen storage, wherein the relevant strategy developed is explained and its application to a PV-dieselbattery-hydrogen system is demonstrated. Chun et al. [9] investigated the scenario of Thailand where they examined the capital cost, net present cost and cost of energy for different types of hybrid systems.

Joseph et al. [10] proposed a microhydro PV hybrid system addressing the issue of sizing a small hydro PV hybrid system for rural electrification in developing countries. Nandi et al. [11] performed a pre-feasibility study of wind-PV-battery hybrid system in eastern southern part of Bangladesh. Lau et al. [12] conducted a performance analysis of hybrid photovoltaic/diesel energy system under Malaysian climatic conditions with a suitability study of utilizing hybrid PV/diesel energy system over stand alone diesel system.

Yadav et al. [13] presented optimal hybrid power system design using HOMER simulation platform where they simulated a wind-diesel hybrid system and presented a comparative analysis in respect of the operational and economic parameters. Kumar and Manoharan [14] analysed hybrid system economy for each climate zone of Tamil Nadu on the basis of net present cost, consumption of diesel and renewable function. Chmeil et al. [15] conducted a study of Scotland and tried alternative configuration which could work more effectively and efficiently. As can be observed from the available literature, optimization of hybrid systems thus far has focused only on technical, economical and environmental aspects. There is lot of scope for research in terms of optimal scheduling in the utilization of solar and wind energy. This paper is an attempt in that direction and this study investigates different scheduling scenarios of hybrid system, consisting of renewable sources viz. solar power, wind power, biomass and battery for storage, and provides the comparison showing the effect on Net Present Cost and Levelized Cost of Energy.

The rest of this paper is organised as follows. The profile of study area is given in section 2. Methodology is discussed in section 3, followed by the mathematical model of renewable energy sources in section 4 . Section 5 discusses the load demand assessment while section 6 shows the potential of renewable energy resources. Section 7 gives the list of component details that comprise the hybrid system. Results are discussed in section 8. A sensitivity analysis is performed in section 9, whereas in section 10 , the conclusion is given.

\section{Profile of the Study Area}

Haryana is the state of India which came into existence on $1^{\text {st }}$ November 1966. It has a total area of $44,212 \mathrm{~km}^{2}$ of which $4 \%$ is

${ }^{*}$ Corresponding author: Ravita Saraswat, School of Renewable Energy and Efficiency, National Institute of Technology, Kurukshetra, Haryana-136 119, India, Tel: 01744233208; E-mail: ravita.saraswat009@gmail.com

Received October 05, 2017; Accepted October 20, 2017; Published October 29, 2017

Citation: Saraswat R, Sathans S (2017) Optimum Scheduling of Isolated Hybrid Renewable Energy System - A Case Study Using HOMER. J Environ Anal Toxicol 7: 520. doi: 10.4172/2161-0525.1000520

Copyright: () 2017 Saraswat R, et al. This is an open-access article distributed under the terms of the Creative Commons Attribution License, which permits unrestricted use, distribution, and reproduction in any medium, provided the original author and source are credited. 
covered by forest and $15 \%$ is the total cropped area [16,17]. There are 21 districts in the State grouped into four divisions. It is situated in the North Western region of India and Himachal Pradesh in its North, Uttrakhand in North East, Rajasthan in the South, U.P and Delhi in the East and Punjab in North West are the other adjoining states as shown in Figure 1. Agriculture has remained and is currently the main leading occupation for the people of the State. The agriculture sector has always been an important contributor to the Gross Domestic Product (GDP) of the State.

The gross area under main crops in the state during 1966-67 was 45.99 lakh hectares. However, during 2013-14 the gross area in state was about 62.43 lakh hectares and during 2014-15 also it was approximately the same as in 2013-14. The contribution of the area under major crops of wheat and paddy to the total gross area was about $58.64 \%$ during 2014-15. The area under wheat crop got reduced from 24.99 lakh hectares in 2013-14 to 24.78 lakh hectares in 2014-15, whereas, the area under commercial crops like sugarcane, cotton and oil seeds etc. has fluctuating trends.

Energy is an important factor for sustained economic growth of any state. However, Haryana has limited availability and potential of natural sources of energy like hydro, coal etc. The total power available in the state from the installed capacity at present is 10,729.04 MW which includes 3230.20 MW from state's own generating stations, 829 MW jointly from its share in central projects and independent private projects. The power available from these sources during the year 201415 is about 17040.3 million units.
Power demand is increasing rapidly in the state and to fulfil the same and also due to environmental concerns there is focus on the use of renewable sources of energy. With this background, this study investigates different scenarios with the available potential of the diverse renewable sources and analyses the performance in respect of optimal scheduling. For this purpose the geographical location of Ramgarh village in Ambala district is selected. The area is located at the height of $275 \mathrm{~m}$ from the main sea level, latitude of $30^{\circ} 21^{\prime} \mathrm{N}$ and longitude of $76^{\circ} 52^{\prime} \mathrm{E}$.

\section{Methodology}

The proposed hybrid renewable energy system, consisting of PV array, wind turbine, biomass generator and battery storage unit, was modelled considering the system parameters specific to the geographical area considered and simulation was carried out using Hybrid Optimization Model for Electrical Renewable (HOMER) [18] software platform developed by National Renewable Energy Laboratory (NREL), U.S. This software is facilitates the simulation of all possible operating conditions of a system and displays the feasible solution that meets the load requirement in an efficient and effective manner [19].

\section{Mathematical models for renewable energy sources}

The hybrid system, investigated in this study, consists of wind turbine, solar PV array, biomass generator and battery storage unit. The modelling of the renewable energy sources was carried out as explained below:

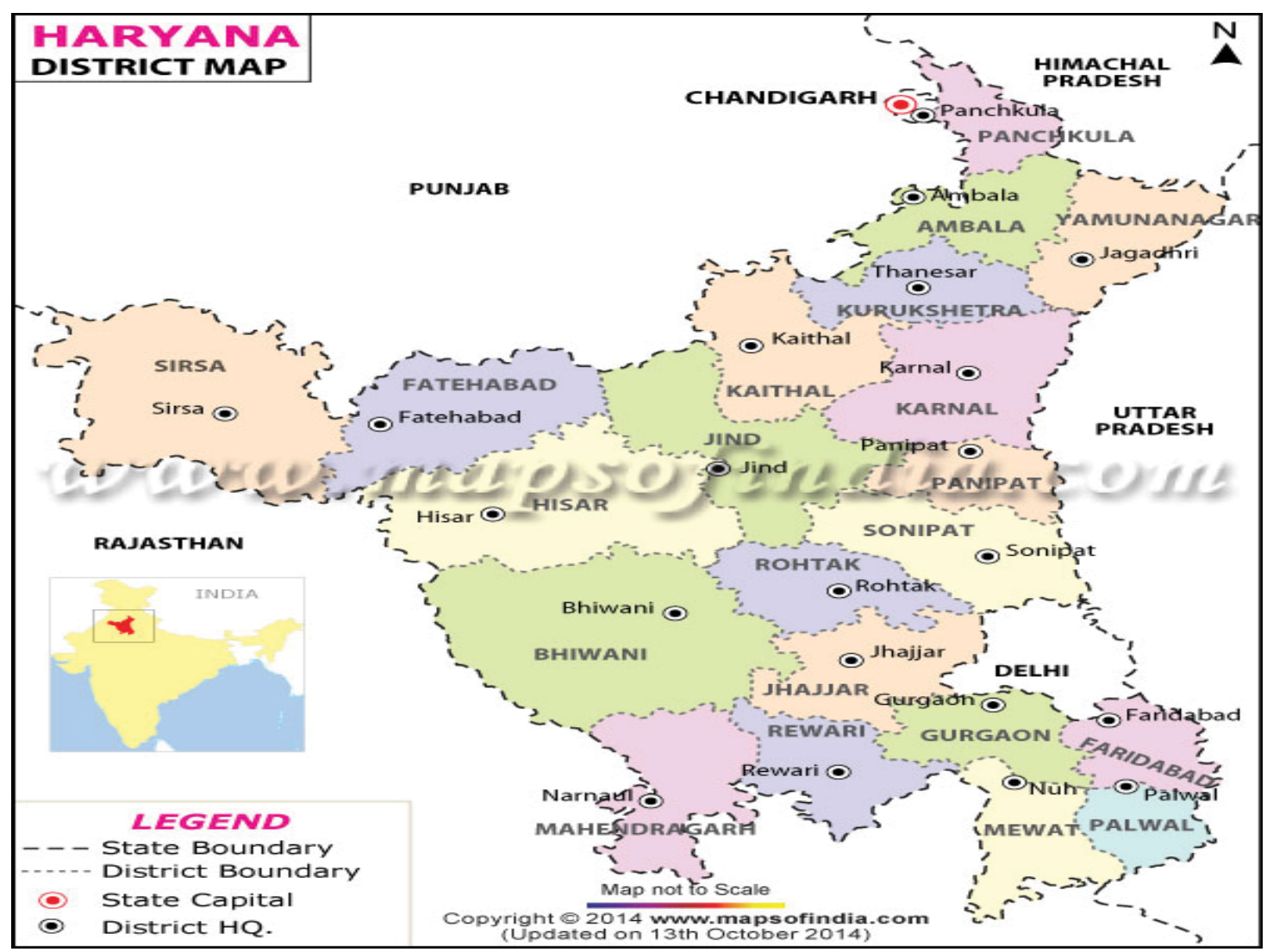

Figure 1: Map of study area [16] 


\section{Wind turbine}

The specific wind turbine, parameters of which are given in Table 1, is selected and the wind power of the same is computed by the software as per Eq. (1) [20]:

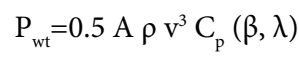

Where, $A=$ rotor swept area in $\mathrm{m}^{2} ; \rho=$ air density in $\mathrm{kg} / \mathrm{m}^{3} ; \mathrm{v}=$ wind velocity $(\mathrm{m} / \mathrm{s}) ; \mathrm{C}_{\mathrm{p}}=$ power co-efficient of wind turbine specific to the wind turbine design; $\beta=$ pitch angle; $\lambda=$ speed ratio.

\section{Solar PV panel}

The specific solar PV array, parameters of which are given in Table 1 , is selected and the output power of the array is computed by the software as per Eq. (2) [20]:

$$
\mathrm{P}_{\mathrm{PV}}=\mathrm{Y}_{\mathrm{PV}} \mathrm{F}_{\mathrm{PV}}\left(\mathrm{G}_{\mathrm{T}} / \mathrm{G}_{\mathrm{T}, \mathrm{STC}}\right)\left[1+\alpha\left(\mathrm{T}_{\mathrm{c}}-\mathrm{T}_{\mathrm{c}, \mathrm{STC}}\right)\right]
$$

Where, $\mathrm{Y}_{\mathrm{PV}}=$ is the rated capacity of the PV array (power output under standard test condition (KW)); $\mathrm{F}_{\mathrm{PV}}=\mathrm{PV}$ derating factor; $\mathrm{G}_{\mathrm{T}}=$ solar radiation incident on the $\mathrm{PV}$ array in current time step (KW/ $\left.\mathrm{m}^{2}\right) ; \mathrm{G}_{\mathrm{T}, \mathrm{STC}}=$ incident radiation at standard test condition $\left(1 \mathrm{KW} / \mathrm{m}^{2}\right)$; $\alpha=$ temperature co-efficient of power $\left(\%{ }^{\circ} \mathrm{C}\right) ; \mathrm{T}_{c}=\mathrm{PV}$ cell temperature in the current time step $\left({ }^{\circ} \mathrm{C}\right) ; \mathrm{T}_{\mathrm{c}, \mathrm{STC}}=\mathrm{PV}$ cell temperature under standard test condition $\left(25^{\circ} \mathrm{C}\right)$

If temperature does not affect the PV array, so that temperature coefficient of power is zero, this equation can be written as:

$$
\mathrm{P}_{\mathrm{PV}}=\mathrm{Y}_{\mathrm{PV}} \mathrm{F}_{\mathrm{PV}}\left(\mathrm{G}_{\mathrm{T}}-\mathrm{G}_{\mathrm{T}, \mathrm{STC}}\right)
$$

\section{Biomass generator}

The hourly electrical power output of biomass gasifier system depends on biomass availability and generating operating hours per day. Biomass output is represented as per the formula given under [21]:

$$
P_{B M G S}=\frac{\text { Total Biomass available }(\text { tons } / \text { Year }) \times C V_{B M} \times \eta_{B M G} \times 1000}{365 \times 860 \times \text { operating hours per day }}
$$

Where, $\mathrm{P}_{\mathrm{BMGS}}=$ hourly output of biomass generator system; $\mathrm{CV}_{\mathrm{BM}}=$ calorific value of biomass; $\eta_{\mathrm{BMG}}=$ overall conversion efficiency of biomass generator system.

Annual energy production of a biomass gasifier based system can be estimated as:

$$
\mathrm{E}_{\text {BMGS }}=\mathrm{P}_{\text {BMGS }}(365 \times 24 \times \text { capacity factor })
$$

\section{Load demand assessment}

The load demand assessment is based on the assumption that there are various types of loads to be catered such as domestic load, commercial load, agriculture load, school load and street light load etc. The assumed electrical load consumption pattern for 24 hours for each month is shown in Figure 2. It can be observed from the figure that load demand is varying over a period of 24 hours and is the maximum in the night hours.

\section{Potential of Renewable Energy Resources Specific to the Area}

\section{Solar energy resource}

The solar radiation data for the area under study has been downloaded from NASA website [22]. Hourly average solar radiation for each month is shown in Figure 3. It is observed from the figure that solar radiation is obtained more during the period from February to May and in the month of October whereas, less solar radiation is available during the period of June to September, and the months of November, December and January.

\section{Wind energy resource}

The wind speed data for the study area has been downloaded from NASA website [22]. The hourly wind speed (measured in $\mathrm{m} / \mathrm{s}$ ) data for each month is shown in Figure 4. It can be seen from the figure that the highest wind speed is obtained in the months of April, May and June.

\section{Hybrid system component parametric details}

The details of the parameters of PV module, wind turbine, biomass generator, battery, converter etc. constituting the proposed hybrid system is given in Table 1. The life period and annual interest rate of this proposed hybrid renewable energy system are assumed to be 25

\begin{tabular}{|c|c|}
\hline Component Description & Specification \\
\hline \multicolumn{2}{|c|}{ Wind Turbine } \\
\hline Rotor Diameter & $2.7 \mathrm{~m}$ \\
\hline Rated Power & $1 \mathrm{KW}$ \\
\hline Start up speed & $3 \mathrm{~m} / \mathrm{s}$ \\
\hline Capital cost & INR 53,500/KW \\
\hline Replacement cost & INR 53,500/KW \\
\hline$O \& M$ cost & INR 3000/yr \\
\hline Lifetime & $15 \mathrm{yrs}$ \\
\hline Hub height & $50 \mathrm{~m}$ \\
\hline \multicolumn{2}{|c|}{ Solar PV Module } \\
\hline Rated Power & $1 \mathrm{KW}$ \\
\hline Lifetime & 20 yrs \\
\hline Derating factor & $90 \%$ \\
\hline Capital cost & INR $80,000 / \mathrm{KW}$ \\
\hline Replacement cost & INR $80,000 / \mathrm{KW}$ \\
\hline $\mathrm{O} \& \mathrm{M}$ cost & INR 2,000/yr \\
\hline \multicolumn{2}{|c|}{ Biomass generator } \\
\hline Rated Power & $1 \mathrm{KW}$ \\
\hline Lifetime (Operating hours) & 15,000 \\
\hline Capital cost & INR $60,000 / \mathrm{KW}$ \\
\hline Replacement cost & INR $60,000 / \mathrm{KW}$ \\
\hline$O \& M$ cost & INR 1.5/hr \\
\hline \multicolumn{2}{|c|}{ Battery } \\
\hline Nominal voltage & $4 \mathrm{~V}$ \\
\hline Nominal capacity & 1,900 Ah(7.6 KWh) \\
\hline Lifetime throughout & $10,569 \mathrm{KWh}$ \\
\hline Capital cost & INR 50,500 \\
\hline Replacement cost & INR 32,500 \\
\hline $\mathrm{O} \& \mathrm{M}$ cost & INR 1,100 /yr \\
\hline \multicolumn{2}{|c|}{ Converter } \\
\hline Rated capacity & $1 \mathrm{KW}$ \\
\hline Lifetime & 15 yrs \\
\hline Efficiency & $90 \%$ \\
\hline Capital cost & INR 7,000/KW \\
\hline Replacement cost & INR $7,000 / \mathrm{KW}$ \\
\hline $\mathrm{O} \& \mathrm{M}$ cost & INR 200/yr \\
\hline
\end{tabular}
years and $6 \%$ respectively.

\section{Results and Discussion}

Optimized results are obtained through simulation using the HOMER software for the following three scenarios:

Table 1: Techno-Economic specifications for the components of proposed system. 
Citation: Saraswat R, Sathans S (2017) Optimum Scheduling of Isolated Hybrid Renewable Energy System - A Case Study Using HOMER. J Environ Anal Toxicol 7: 520. doi: 10.4172/2161-0525.1000520

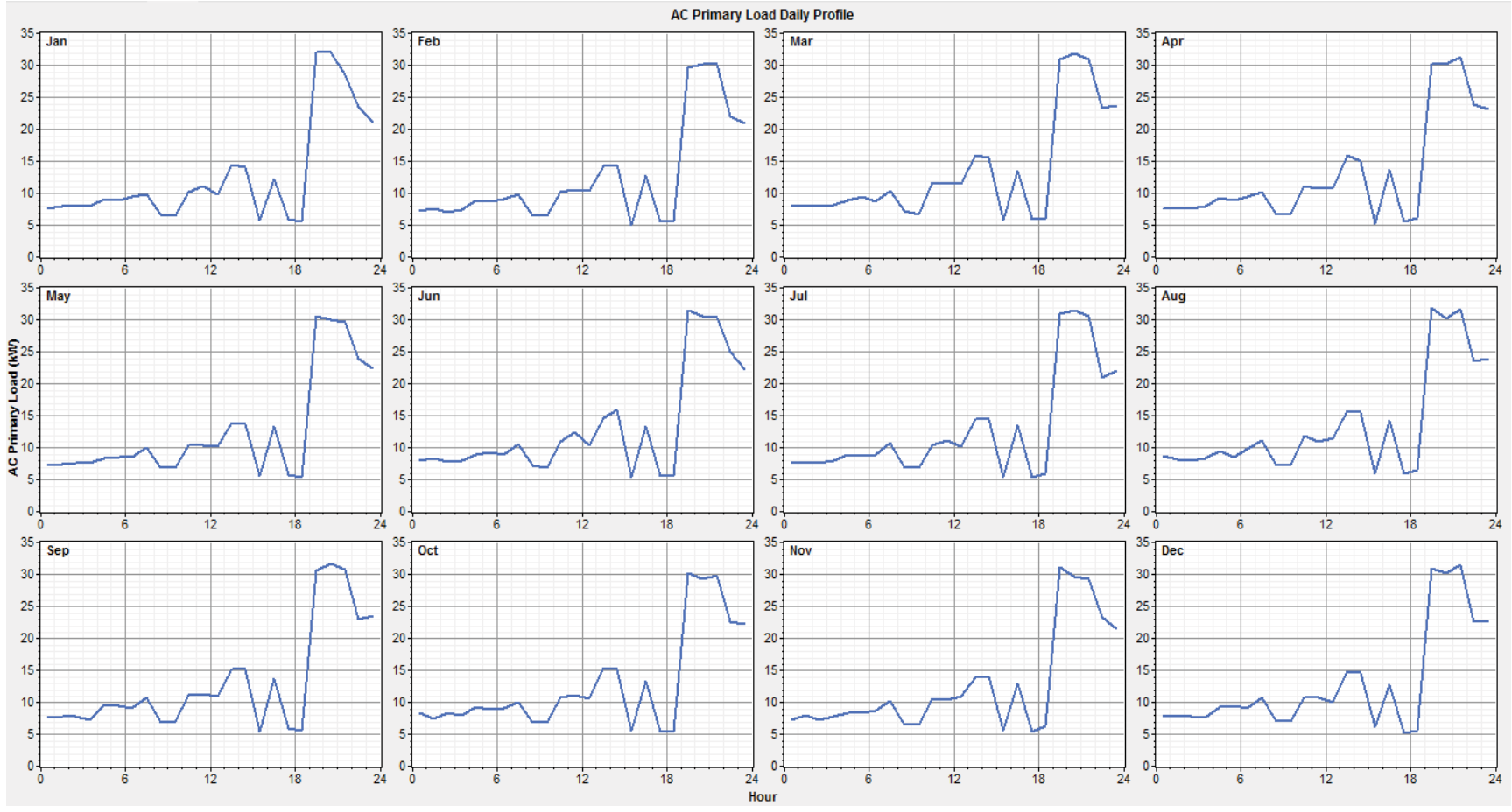

Figure 2: 24 hours load demand for each month.

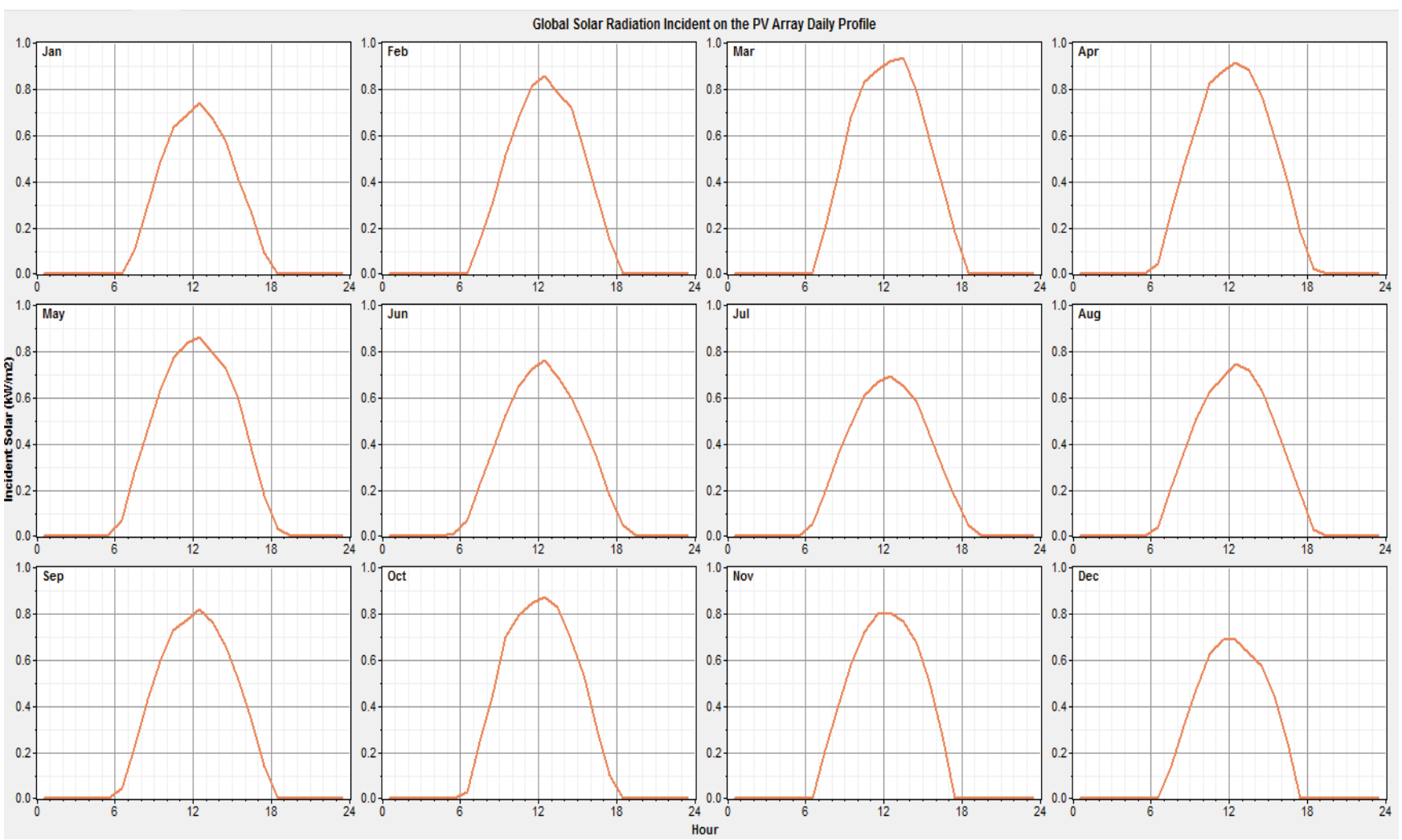

Figure 3: Hourly average solar radiation for each month. 

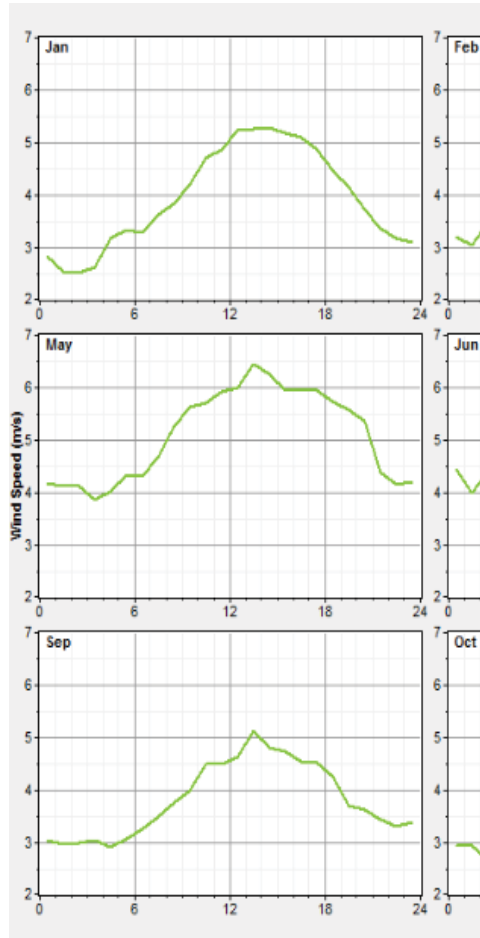
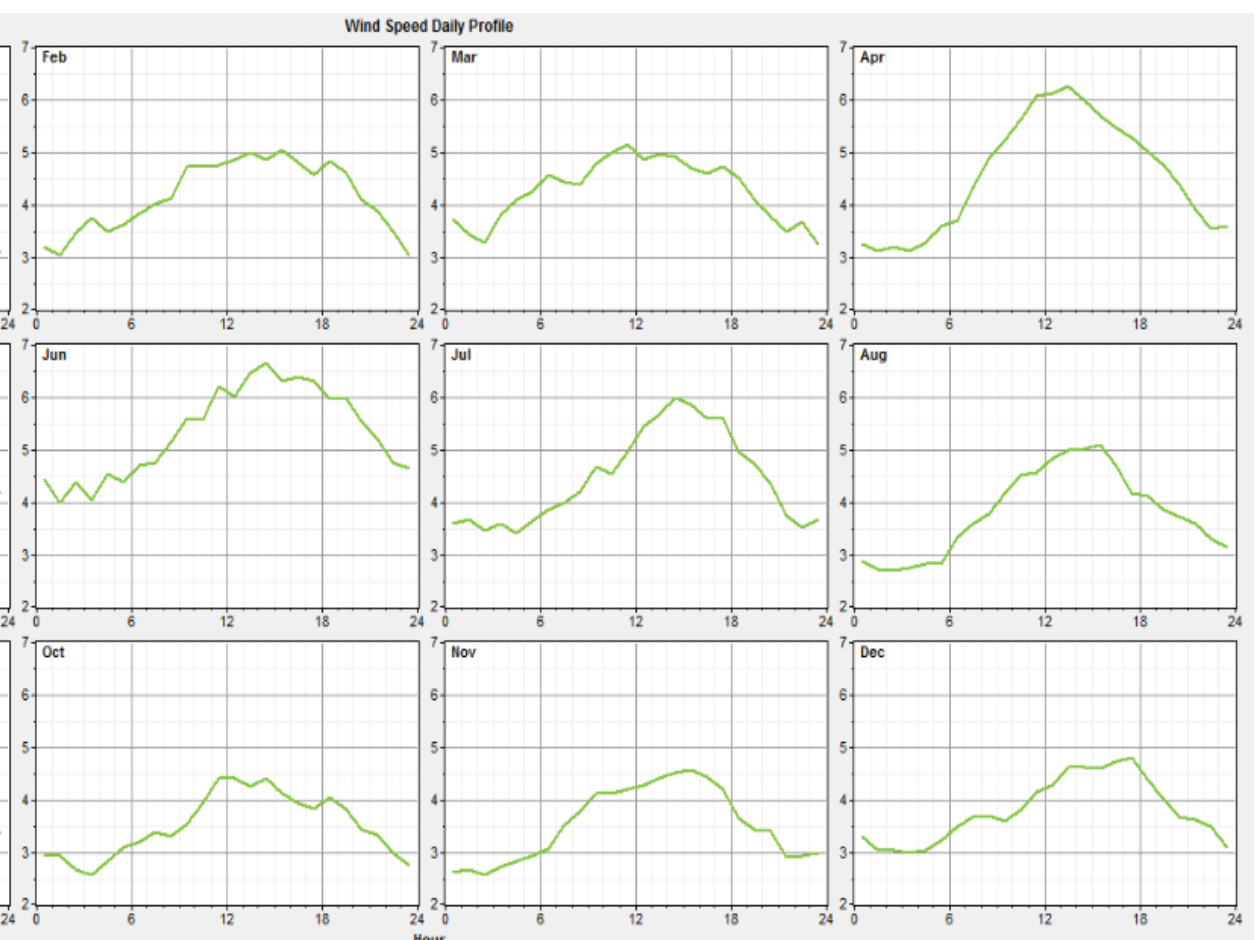

Figure 4: Hourly average wind speed for each month.

(i) When Biomass generator is scheduled depending upon the solar and wind availability for each month.

(ii) Biomass generator is forced on all time.

(iii) Biomass generator is optimized with the system requirement.

\section{Scenario-I}

In scenario-I, biomass generator is switched on or off depending upon the load requirement and availability of solar radiation and wind speed. The generator on-off time for each month is shown in Figure 5. Figures 6 and 7 show the simulated results, in terms of share of each resource in the total generated power month wise. The quantitative comparison of the three scenarios is given in Table 2 with system configuration, cost economics, power production, biomass generator utilization and emissions as the performance parameters. In scenario-I, the share of power generated by solar PV array is the highest among all sources as is evident from the Table 2 where power generated by PV, wind and biomass generator is $115,619 \mathrm{KWh} / \mathrm{yr}, 20,596 \mathrm{KWh} / \mathrm{yr}$ and $62,222 \mathrm{KWh} / \mathrm{yr}$ respectively.

\section{Scenario-II}

In this scenario, Generator is forced on all time irrespective of availability of solar radiation and wind speed. Figures 8 and 9 show the simulated results, in terms of share of each resource in the total generated power month wise. In scenario-II, the share of power generated by biomass generator is the highest among all sources as is evident from the Table 2 where power generated by PV, wind and biomass generator is $19,270 \mathrm{KWh} / \mathrm{yr}, 1,373 \mathrm{KWh} / \mathrm{yr}$ and 107, 397 $\mathrm{KWh} / \mathrm{yr}$ respectively.

\section{Scenario-III}

In this scenario, the renewable energy sources which constitute the hybrid system under investigation are scheduled in optimized manner as per requirement. Figures 10 and 11 show the simulated results in terms of share of each resource in the total generated power month wise. In this scenario, the share of power generated by biomass generator is the highest among all sources as is evident from the Table 2 where power generated by $\mathrm{PV}$, wind and biomass generator is 57,810 $\mathrm{KWh} / \mathrm{yr}, 4,119 \mathrm{KWh} / \mathrm{yr}$ and 74,580 KWh/yr respectively.

From Table 2, it is noticed that the number of PV panel and wind turbine units are maximum for scenario-I as compared to the other two scenarios. In scenario-I, not only the NPC and LCOE are high but the total energy production, excess electricity and unmet load in $\mathrm{KWh} / \mathrm{yr}$ are also highest among all scenarios. Whereas, in scenarioII, the biomass generator fuel consumption is the highest along with the $\mathrm{CO}_{2}, \mathrm{NO}_{2}, \mathrm{CO}$ and hydrocarbons emissions also being the highest in scenario-II. Net present cost is one of the most important parameters for any system. However, cheaper system may not always be a preferred solution. Other parameters like biomass consumption, generating hours, pollutant emissions etc. can be considered important while selecting the best suitable system. Depending upon the priority consideration the choice of suitable scenario can be made as the potential solution.

\section{Sensitivity analysis}

Sensitivity analysis has been performed for different maximum annual capacity storage in relation to change in net present cost and levelized cost of energy. The impact of variation in maximum annual capacity storage on net present cost and levelized cost of energy is 
Citation: Saraswat R, Sathans S (2017) Optimum Scheduling of Isolated Hybrid Renewable Energy System - A Case Study Using HOMER. J Environ Anal Toxicol 7: 520. doi: 10.4172/2161-0525.1000520

Page 6 of 10

\begin{tabular}{|c|c|c|c|c|c|}
\hline & & Unit & Scenario-I & Scenario-II & Scenario-III \\
\hline \multirow{5}{*}{ System Configuration } & PV Panel & $\mathrm{KW}$ & 60 & 10 & 30 \\
\hline & Wind turbine & Number & 15 & 1 & 3 \\
\hline & Biomass generator & $\mathrm{KW}$ & 15 & 15 & 35 \\
\hline & Battery & Number & 50 & 40 & 40 \\
\hline & Converter & $\mathrm{KW}$ & 45 & 45 & 20 \\
\hline \multirow{2}{*}{ Economic } & Total NPC & INR & 18,779085 & $14,969,695$ & $15,107,755$ \\
\hline & Total LCOE & INR & 12.935 & 10.27 & 10.4 \\
\hline \multirow{6}{*}{ Power production } & PV Panel & $\mathrm{KWh} / \mathrm{yr}$ & 115,619 & 19,270 & 57,810 \\
\hline & Wind turbine & $\mathrm{KWh} / \mathrm{yr}$ & 20,596 & 1,373 & 4,119 \\
\hline & Biomass & $\mathrm{KWh} / \mathrm{yr}$ & 62,222 & 107,397 & 74,580 \\
\hline & Total Energy Production & $\mathrm{KWh} / \mathrm{yr}$ & 198,438 & 128,040 & 136,508 \\
\hline & Excess Electricity & $\mathrm{KWh} / \mathrm{yr}$ & 68,801 & 1,375 & 6,252 \\
\hline & Unmet Load & $\mathrm{KWh} / \mathrm{yr}$ & 66.6 & 60.3 & 3.12 \\
\hline \multirow{3}{*}{ Biomass Generator Set } & Biomass generator fuel consumption & Tons/yr & 30.3 & 53.4 & 37.5 \\
\hline & Biomass Generator set hours & $\mathrm{hr} / \mathrm{yr}$ & 4,713 & 4,760 & 2,721 \\
\hline & Biomass generator starts & st/yr & 316 & 1 & 481 \\
\hline \multirow{4}{*}{ Emissions } & $\mathrm{CO}_{2}$ & $\mathrm{Kg} / \mathrm{yr}$ & 5.24 & 9.23 & 6.49 \\
\hline & $\mathrm{NO}_{2}$ & $\mathrm{Kg} / \mathrm{yr}$ & 1.76 & 3.1 & 2.18 \\
\hline & $\mathrm{CO}$ & $\mathrm{Kg} / \mathrm{yr}$ & 0.197 & 0.347 & 0.244 \\
\hline & Hydrocarbons & $\mathrm{Kg} / \mathrm{yr}$ & 0.0218 & 0.384 & 0.027 \\
\hline
\end{tabular}

Table 2: Comparison between the three scenarios.

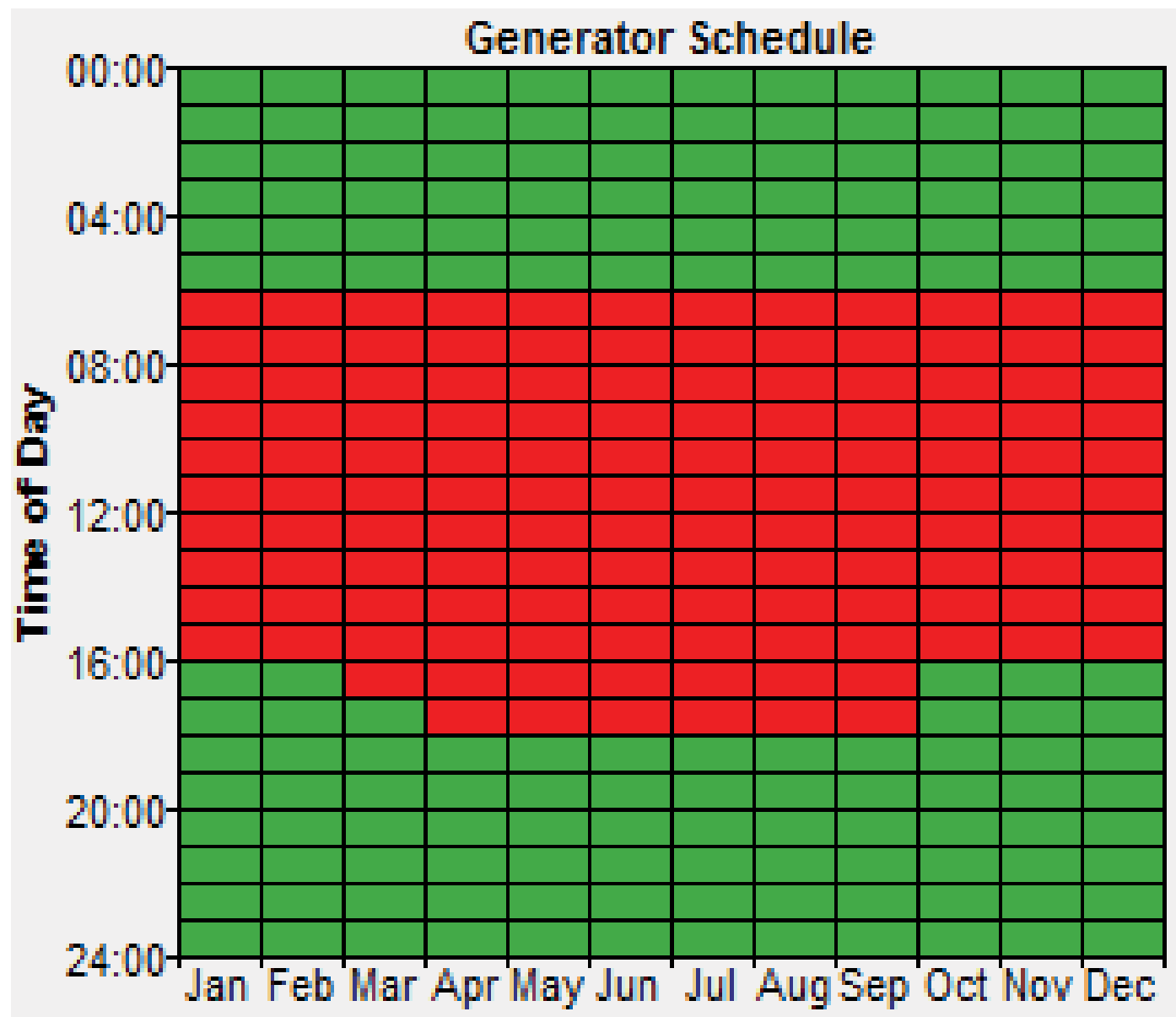

Figure 5: Generator schedule time for each month. 
Citation: Saraswat R, Sathans S (2017) Optimum Scheduling of Isolated Hybrid Renewable Energy System - A Case Study Using HOMER. J Environ Anal Toxicol 7: 520. doi: 10.4172/2161-0525.1000520

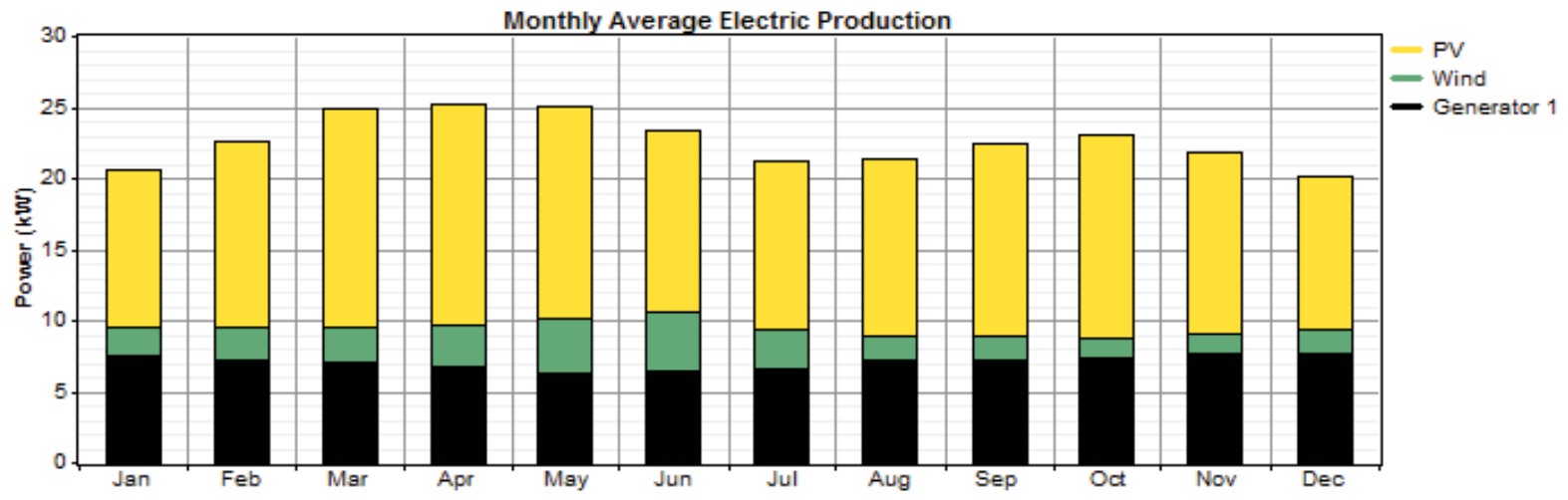

Figure 6: Monthly average energy production for scenario-I.

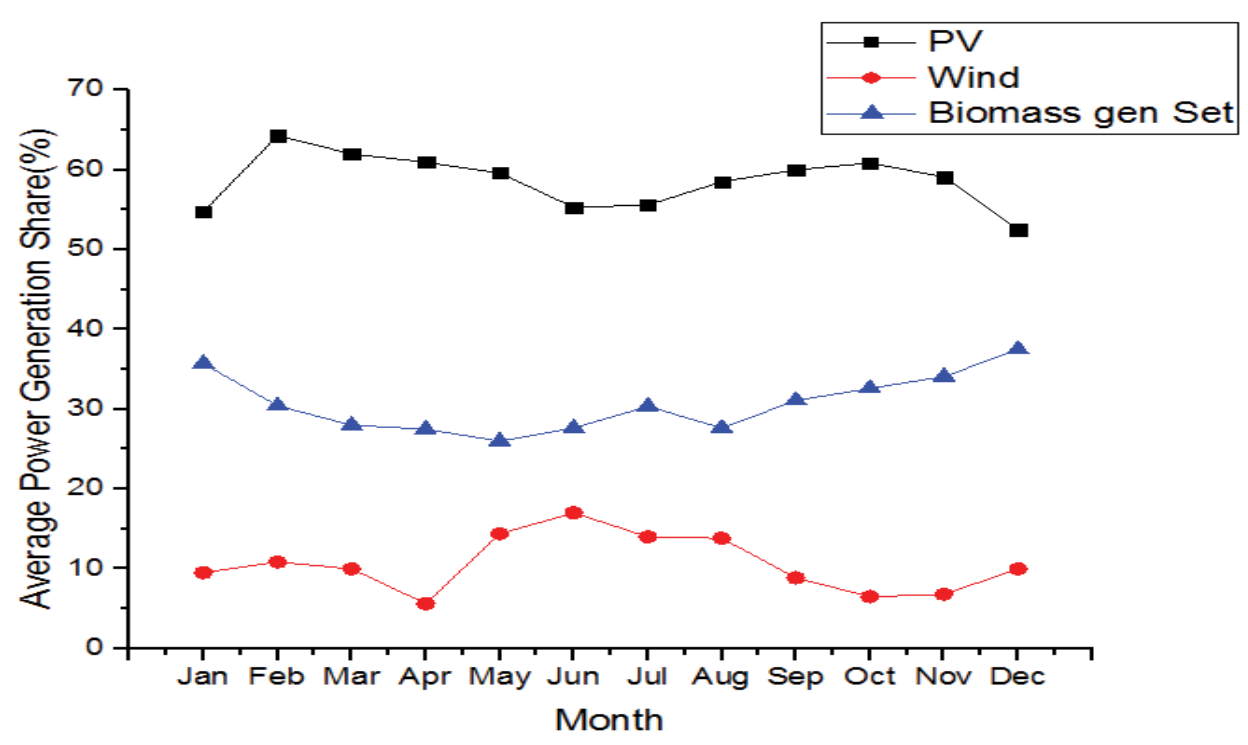

Figure 7: Average power generation shares (\%) for scenario-I.

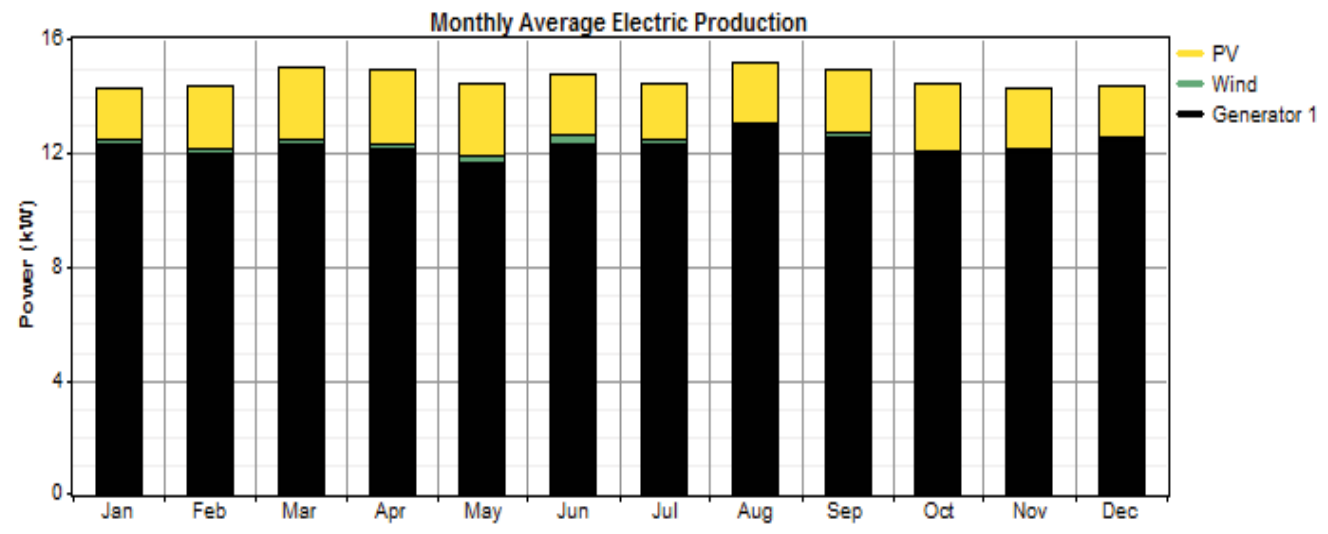

Figure 8: Monthly average energy production for scenario-II. 
Citation: Saraswat R, Sathans S (2017) Optimum Scheduling of Isolated Hybrid Renewable Energy System - A Case Study Using HOMER. J Environ Anal Toxicol 7: 520. doi: 10.4172/2161-0525.1000520

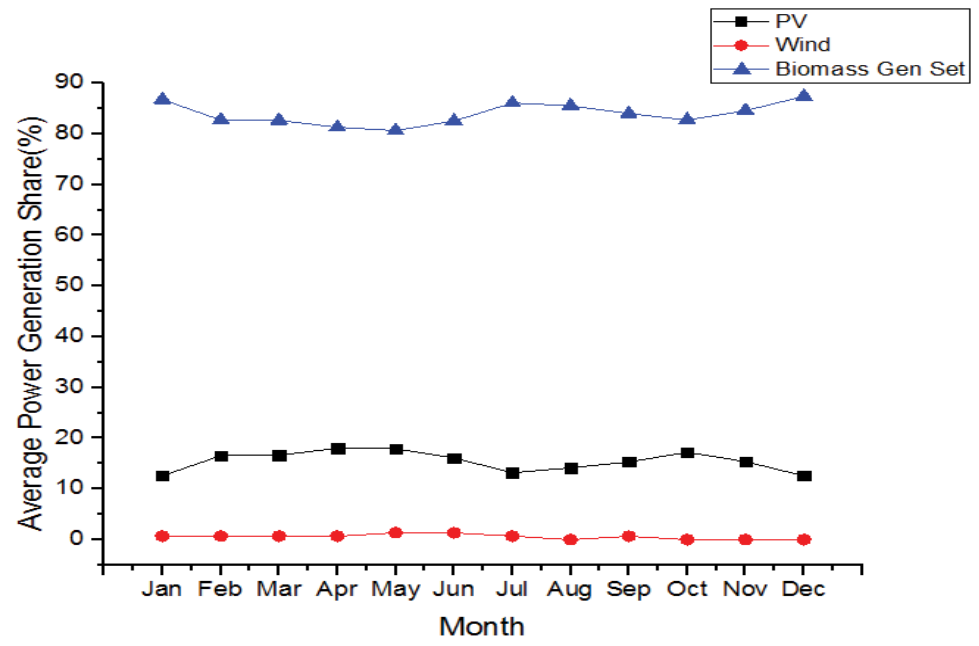

Figure 9: Average power generation shares (\%) for scenario-II.

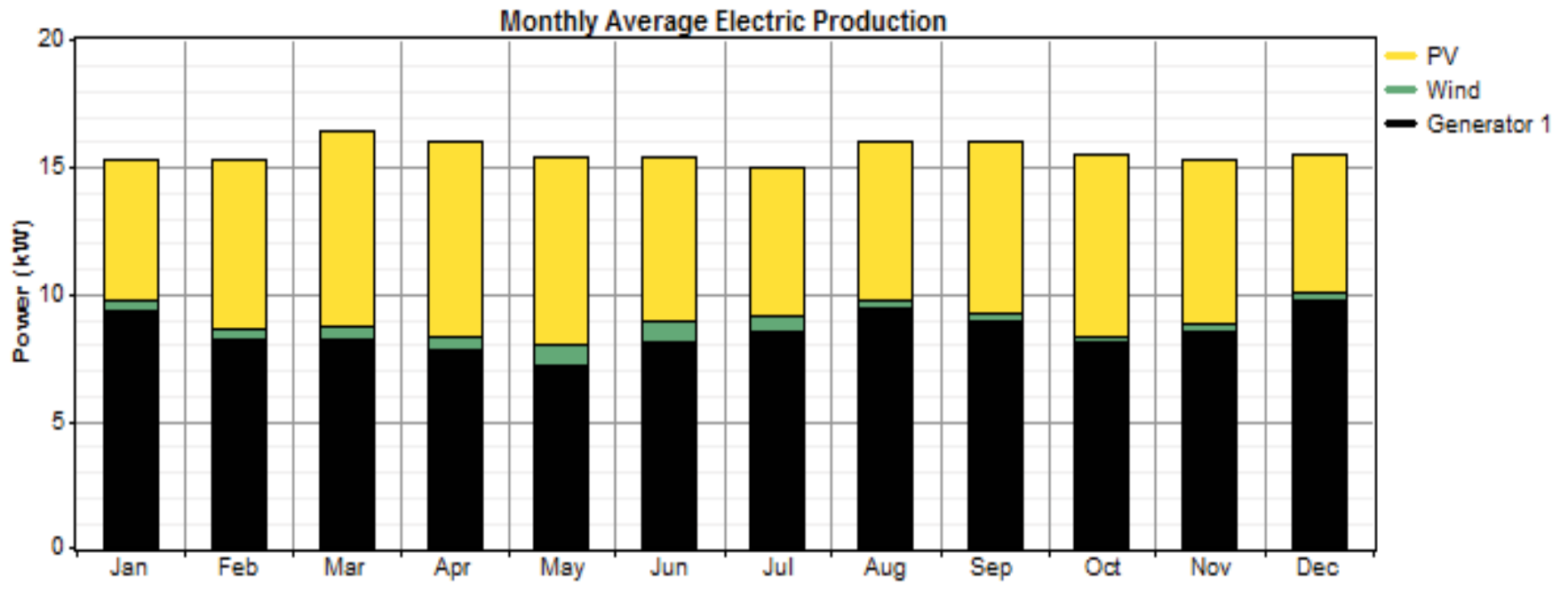

Figure 10: Monthly average energy production for scenario-III.

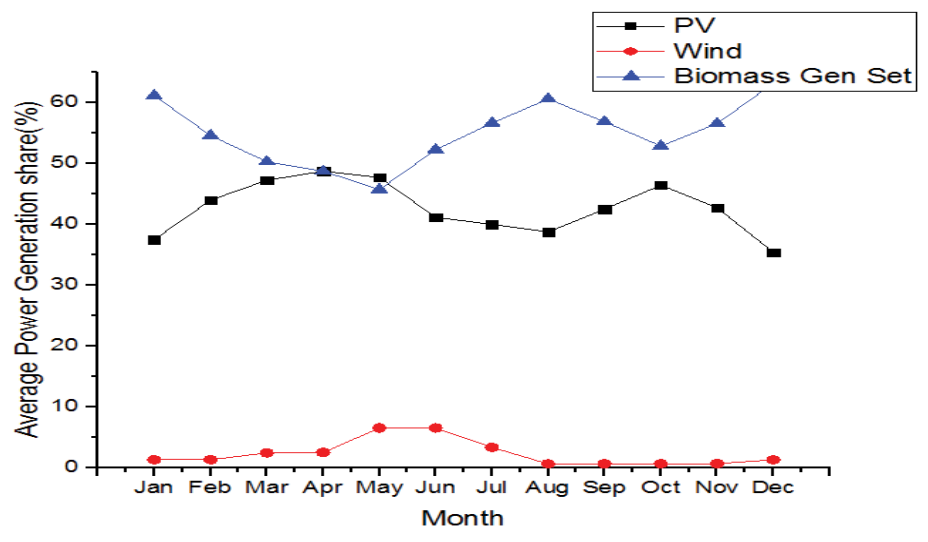

Figure 11: Average power generation share (\%) for scenario-III. 


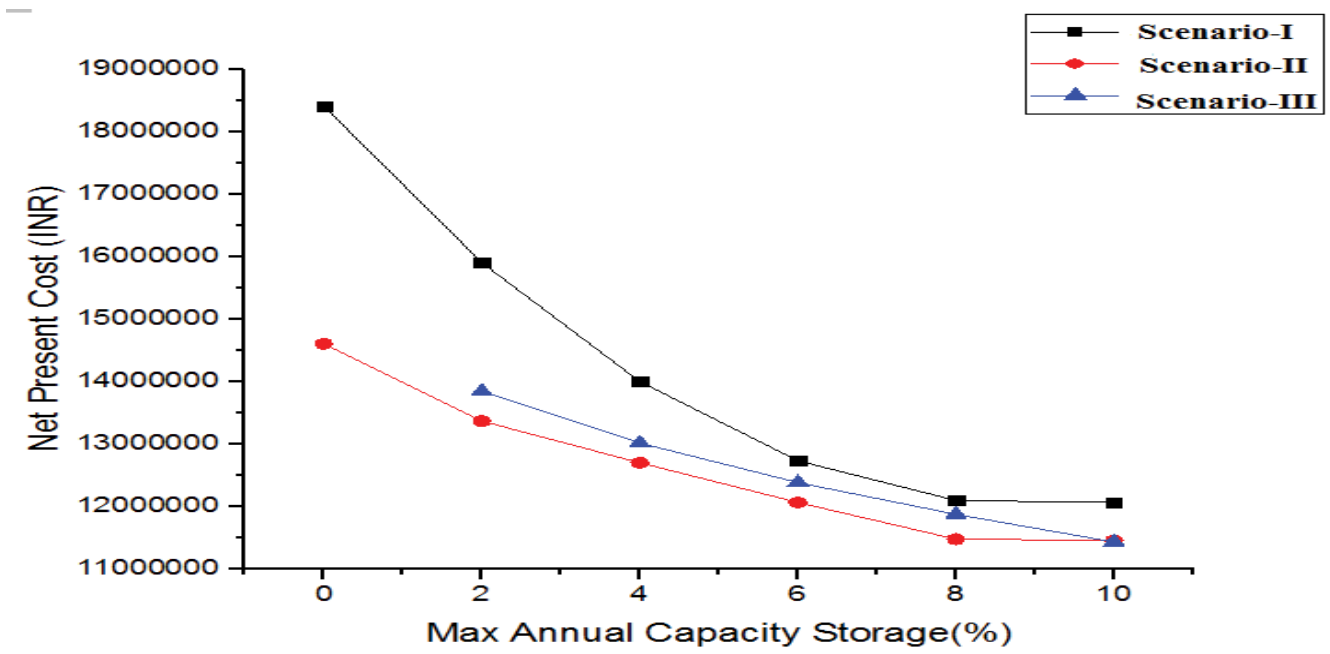

Figure 12: Effect of varying Maximum Annual Capacity storage on Net Present Cost.

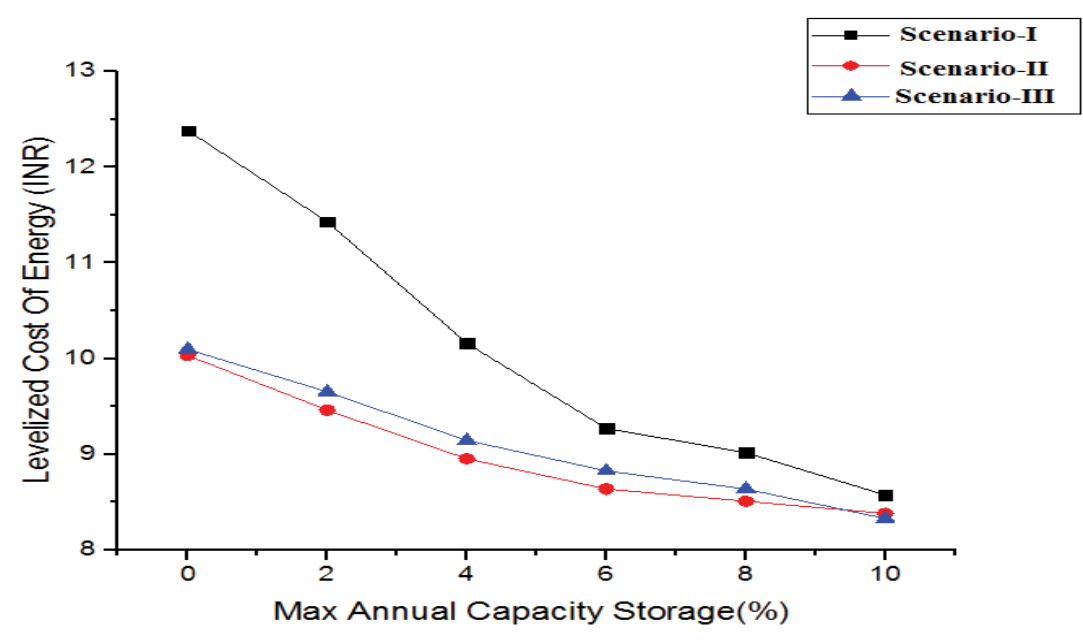

Figure 13: Effect of varying maximum annual capacity storage on Levelized Cost of Energy.

shown in Figures 12 and 13. As is evident from the figures, net present cost and levelized cost of energy get decreased by increasing maximum annual capacity storage for all the three scenarios considered.

\section{Conclusion}

Solar and wind energy could be the potential solution to cater to the increasing load demand, scarcity of fossil fuels and green house effect. However, the main limitation of solar and wind energy is the higher cost of energy production. This problem can, to some extent, be overcome by proper scheduling and time utilization for solar and wind energy according to their availability. There are very few works reported on the scheduling concept in this area. This paper, in that scope of work, has investigated and presented the comparison of the different scheduling scenarios for hybrid renewable energy system in terms of system configuration, economy, power production, biomass availability and pollutant emission. As per the results of this study, from the economic point of view, scenario-II is considered to be most feasible as net present cost and levelized cost of energy are least in this scenario but biomass consumption is very large. From the emission point of view, scenario-I is found to be the most feasible solution as $\mathrm{CO}_{2}, \mathrm{NO}_{2}, \mathrm{CO}$ and hydrocarbons emissions are the least in this scenario. Sensitivity analysis has been performed w.r.t. varying maximum annual capacity storage vis-a-vis the change in net present cost and levelized cost of energy and it is observed that increase in maximum annual capacity storage results in decrease in the net present cost and levelized cost of energy.

\section{References}

1. Al-Masri H, Amoura F (2015) Feasibility study of a grid connected hybrid wind/ PV system. In: Environment and Electrical Engineering (EEEIC), 2015 IEEE 15th International Conference on 2015, pp: 2194-2199.

2. Malheiro A, Castro PM, Lima RM, Estanqueiro A (2015) Integrated sizing and scheduling of wind/PV/diesel/battery isolated systems. Renewable Energy 83: 646-657. 
Citation: Saraswat R, Sathans S (2017) Optimum Scheduling of Isolated Hybrid Renewable Energy System - A Case Study Using HOMER. J Environ Anal Toxicol 7: 520. doi: 10.4172/2161-0525.1000520

3. Chauhan A, Saini RP (2014) A review on integrated renewable energy system based power generation for stand-alone applications: configurations, storage options, sizing methodologies and control. Renewable and Sustainable Energy Reviews 38: 99-120.

4. Pérez-Navarro A, Alfonso D, Ariza HE, Cárcel J, Correcher A, et al. (2016) Experimental verification of hybrid renewable systems as feasible energy sources. Renewable Energy 86: 384-391.

5. Ismail MS, Moghavvemi M, Mahlia TM, Muttaqi KM, Moghavvemi S (2015) Effective utilization of excess energy in standalone hybrid renewable energy systems for improving comfort ability and reducing cost of energy: A review and analysis. Renewable and Sustainable Energy Reviews 42: 726-734.

6. Mahesh A, Sandhu KS (2015) Hybrid wind/photovoltaic energy system developments: Critical review and findings. Renewable and Sustainable Energy Reviews 52: 1135-1147.

7. Bernal-Agustín JL, Dufo-López R, Rivas-Ascaso DM (2006) Design of isolated hybrid systems minimizing costs and pollutant emissions. Renewable Energy 31: $2227-2244$

8. Dufo-Lopez R, Bernal-Agustín JL, Contreras J (2007) Optimization of control strategies for stand-alone renewable energy systems with hydrogen storage. Renewable Energy 32: 1102-1126.

9. Fung CC, Rattanongphisat W, Nayar C (2002) A simulation study on the economic aspects of hybrid energy systems for remote islands in Thailand. In: TENCON'02. Proceedings. 2002 IEEE Region 10 Conference on Computers, Communications, Control and Power Engineering 3: 1966-1969.

10. Kenfack J, Neirac FP, Tatietse TT, Mayer D, Fogue M, et al. (2009) MicrohydroPV-hybrid system: Sizing a small hydro-PV-hybrid system for rural electrification in developing countries. Renewable Energy 34: 2259-2263.

11. Nandi SK, Ghosh HR (2010) Prospect of wind-PV-battery hybrid power system as an alternative to grid extension in Bangladesh. Energy 35: 3040-3047.
12. Lau KY, Yousof MF, Arshad SN, Anwari M, Yatim AH (2010) Performance analysis of hybrid photovoltaic/diesel energy system under Malaysian conditions. Energy 35: 3245-3255.

13. Yadav DK, Girimaji SP, Bhatti TS (2010) Optimal hybrid power system design using HOMER. In: Power Electronics (IICPE), 2012 IEEE 5th India International Conference on 2012, pp: 1-6

14. Kumar US, Manoharan PS (2014) Economic analysis of hybrid power systems (PV/diesel) in different climatic zones of Tamil Nadu. Energy Conversion and Management 80: 469-476.

15. Chmiel Z, Bhattacharyya SC (2015) Analysis of off-grid electricity system at Isle of Eigg (Scotland): Lessons for developing countries. Renewable Energy 81: $578-588$.

16. State Industrial profile of Haryana 2015-16. Available from: http://dcmsme gov.in/dips/state_wise_dips/state\%20profile\%20haryana.pdf [Assessed on 20.07.15].

17. Economic Survey of Haryana 2014-2015. Available from: http://esaharyana gov.in/Data/Economic\%20Survey\%20of\%20Haryana/2014-15.pdf [Assessed on 20.07.15].

18. Hybrid Optimization Model for Electric Renewable Energy (HOMER). Available from: http://homerenergy.com/download.asp [Accessed on 10.06.15].

19. Rezzouk H, Mellit A (2015) Feasibility study and sensitivity analysis of a standalone photovoltaic-diesel-battery hybrid energy system in the north of Algeria. Renewable and Sustainable Energy Reviews 43: 1134-1150.

20. Fathima AH, Palanisamy K (2015) Optimization in microgrids with hybrid energy systems-A review. Renewable and Sustainable Energy Reviews 45: 431-446.

21. Chauhan A, Saini RP (2015) Renewable energy based off-grid rura electrification in Uttarakhand state of India: Technology options, modelling method, barriers and recommendations. Renewable and Sustainable Energy Reviews 51: 662-681.

22. Solar and Wind Data. Available form: http://power.larc.nasa.gov/ [Accessed on 12.07.15]. 